\title{
Different Aspects about the Position of Albanians in Montenegro
}

\author{
Dr. Sci. Veton Zejnullahi
}

\section{Doi:10.5901/mjss.2015.v6n2s5p273}

\begin{abstract}
Albanians of Montenegro as an integral and indivisible part of the Albanian nation in its land in Montenegro constitute 4. 91\% of the total population of the state. The Albanian population in Montenegro is characterized by a powerful diaspora primarily located in the United States of America, and after the war in Kosovo many Albanian citizens from there settled in Kosovo looking for a better life. Although a small percentage in number compared with other nations, Albanians in Montenegro have played an important role in political life and for the future of the state. We must ascertain role and the importance of the Albanian vote in the referendum organized for secession of Montenegro from the State Union of Serbia, which was decisive in achieving the final result in favor of independence. Albanians were the first nation who formed their own political parties, thus supporting Montenegro to become a multiparty state. During the war for the liberation of Kosovo, Albanians in Montenegro played a tremendous role ranging from financing, direct participation in the war, especially in accommodating, hospitality of Kosovo Albanian IDPs in their private home, public buildings, and mosques. The same roles played also the Bosnians population living in Montenegro. Albanian political organization starts with political pluralism and there currently operate several political parties but also the National Council of Albanians.
\end{abstract}

Keywords: Montenegro, referendum, Albanians, national rights, the National council

\section{Introduction}

Republic of Montenegro after the Second World War was part of the SFRY, consisting of six republics and two provinces. Montenegro was the smallest republic for the territory and for the number of population, but with a very favorable geostrategic position, because among other things also has access to the Adriatic Sea. Since the beginning of the dissolution of former Yugoslavia, the tiny republic of the Yugoslav federation became the target of attacks by Serb nationalists. In the so-called "Ant bureaucratic Revolution " after massive protests in Titograd (Podgorica today) in January 1989 party and state leadership of Montenegro resigned, replaced by allies of the Slobodan Milosevic. After the Yugoslav federation was dissolved in April 1992 with the independence of the republics of the then, in the federation remained only Serbia and Montenegro, announced the Federal Republic of Yugoslavia (FRY) on 27 April 1992. After this period, although the former allies and relation between the two republics began to fester, especially after NATO's intervention during the war in Kosovo. In 2003, the Federal Republic of Yugoslavia was reconstituted and changed its name to the State Union of Serbia and Montenegro, but the union was not long-lived, and was dissolved by the declaration of independence of Montenegro on 3 June 2006. For this reason the referendum was organized, which leaded to the mobilization of non-Serb peoples of Montenegro for a massive participation. Precisely in the referendum held on 21. 05. 2006 Albanian citizens traveled from Europe, America and many remote locations with the intention of declaring independence of Montenegro. Albanian vote increased this value due to the fact that the international community demanded from Montenegro to declare independence, not $51 \%$ as usual, but $55 \%$ of the citizens. The results demonstrate the importance of the Albanian vote, because in the end it turned out that $55.5 \%$ of the citizens of Montenegro declared the independence of their country. Viewed in municipalities where Albanians live observe a massive output and a deep result in favor of independence as for example in Ulqin 88. 50\%, in Plavë 78. 92\%, and 91. $33 \%$ in Rozhaje ${ }^{1}$. It is very interesting that this referendum joined the Albanian political factor and acted in the interest of the declaration of independence of Montenegro, even being decisive in the final outcome, but otherwise never managed to join and appear unique and a joint list for the national elections and that in turn will bring the greatest number of Albanian MPs in the Parliament of Montenegro.

${ }^{1}$ http://www.osce.org/sr/odihr/elections/montenegro/20099?download=true 


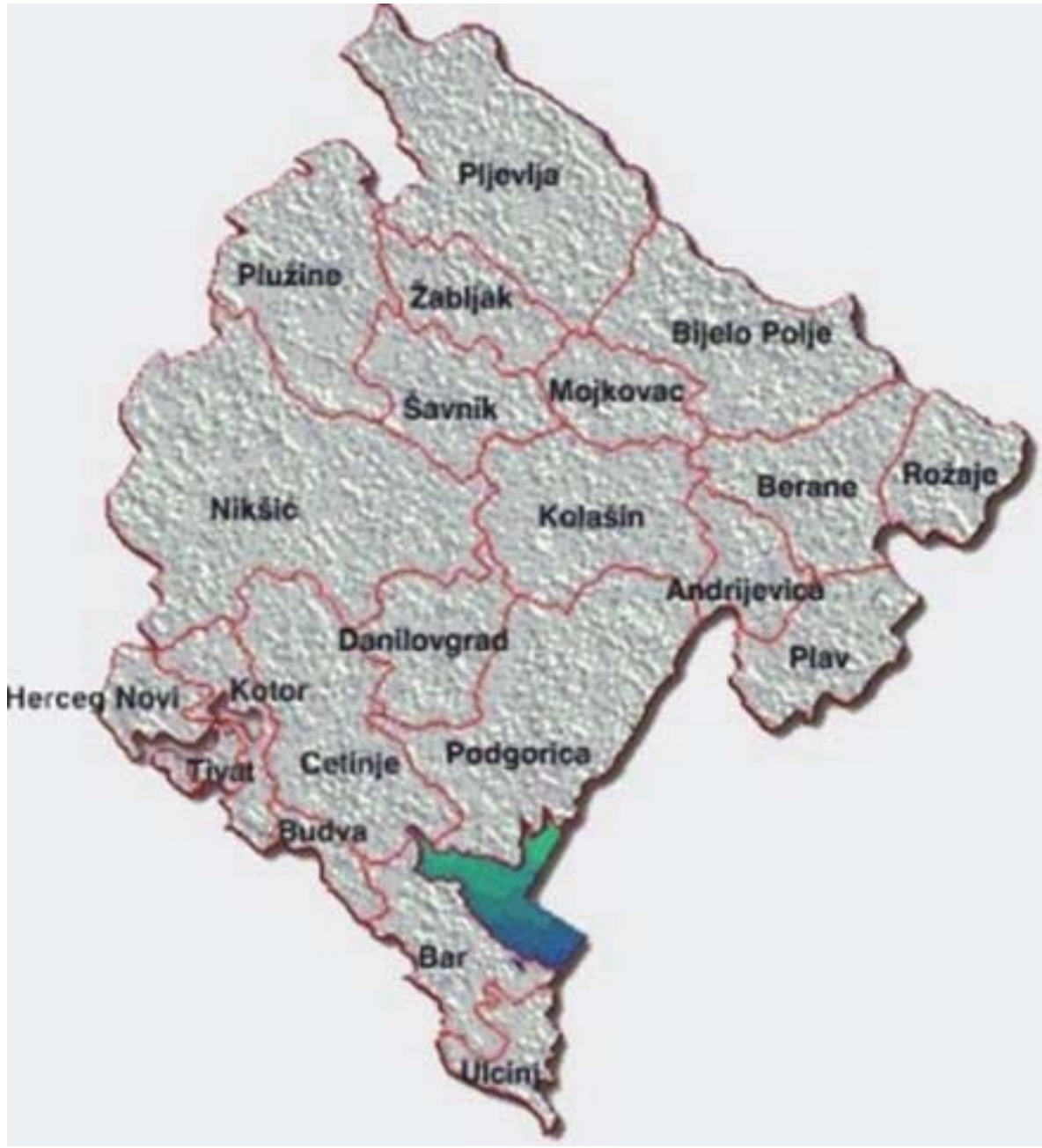

Map of Montenegro ${ }^{2}$

\section{The Purpose of the Paper}

The purpose of this paper is to show the state of Albanians in Montenegro, focusing on the historical, political, economic, education, health, national rights - the symbols and language, information, migration and many other problems facing Albanian population in this Republic. Also, will emphasize the role of Montenegro during the war that led to the breakup of the Yugoslav federation and the process of independence of Montenegro and the role of Albanians in the process.

Viewed from the historical aspect Montenegro has a sensational stories ranging from ancient times when it was Illyrian territory to the rule of the Ottoman Empire centuries was part of the Vilayet of Shkodra, which in itself had four Albanian and Montenegrin kaza up the Treaty of San Stefano in 1878 and the Congress of Berlin that year when was recognised as Slavic state. Thanks to the Treaty of San Stefano and Berlin Congress, Montenegro were added thousands of square miles including much land that today is part of Montenegro? Ulcinj, Bar, Tuzi, Hoti, Gruda, Rozaje, Plav, Gucia are Albanian lands were given to Montenegro.

In general, the Treaty of San Stefano Montenegro will be given a territory of $15,700 \mathrm{~km} 2 .{ }^{3}$ And included a threefold greater territory, but which would revise the Treaty of Berlin was given an area of $9,100 \mathrm{~km} 2 \cdot 4$

2 http://www.cgautentik.com/index_o_crnoj_gori.php

3 Puto, Arben,Cështja shqiptare në aktet ndërkombëtare të periudhës së imperializmit (1867-1912), vëllimi l, Tiranë 1984, pg.16

${ }_{4}^{4}$ Po aty,pg.16 
Map of Albanian vilajets 5

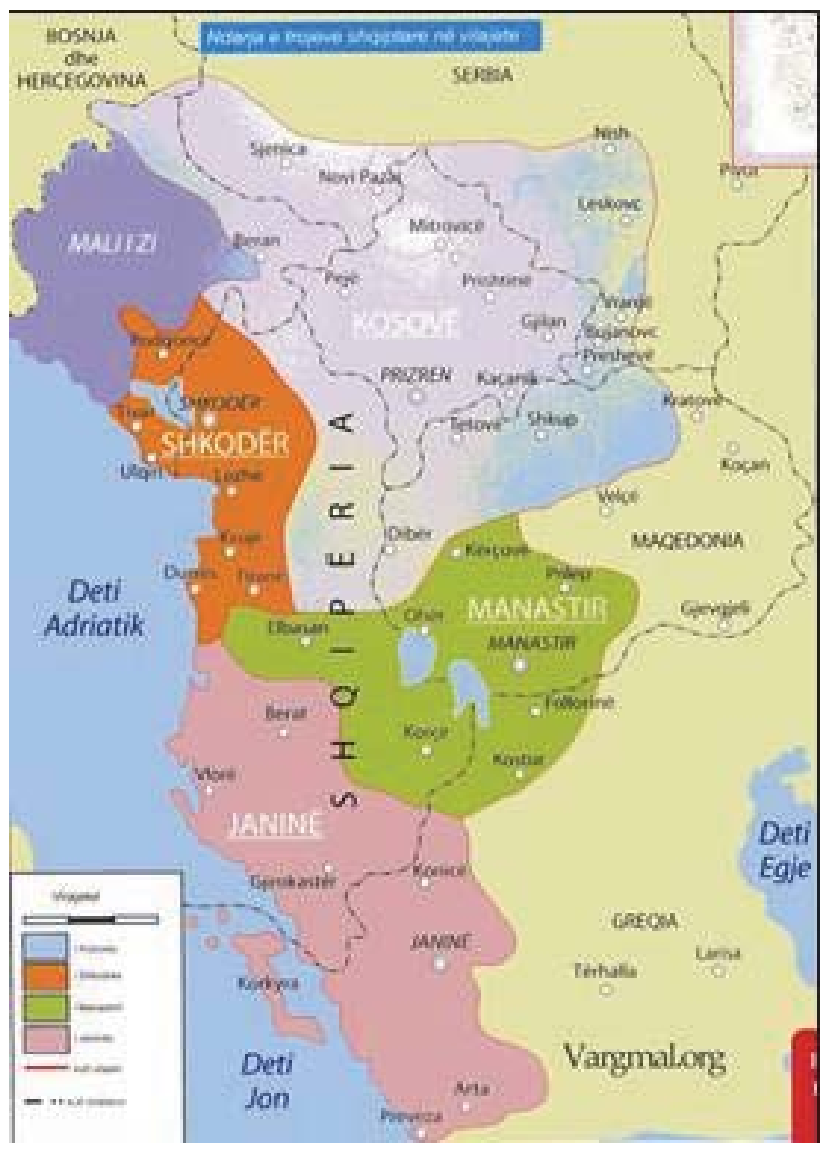

\section{Political Developments in the Nineties of the 20-th Century}

After the collapse of communism and the introduction of political pluralism throughout Eastern Europe and the former Yugoslavia and, consequently, Montenegro was involved in this huge wave of change moving from one-party system of state organization in the pluralist parliamentary democracy. Albanians were the first who formed their own political parties initially with the Democratic League of Montenegro and later was enriched with other Political parties. Otherwise past two decades pluralist lives in Montenegro are formed over a hundred political parties, but most of them were short life.

Montenegro as part of the Federal Republic of Yugoslavia along with Serbia could turn the bloody wars that led to the breakup of the former SFRY, the more so since the beginning of the war in Croatia more volunteers peered Montenegrin side by side with the Serbian military and paramilitary formations in the war against Croats claiming to participate Croatian territory respectively strategic part called Konavle and Prevlaka, and were marked especially during the bombing of the city of Dubrovnik. However, after the departure of Momir Bulatovic from Montenegrin political scene, Milo Djukanovic's government distanced itself from invasive wars concentrating on preparing Montenegro for secession from Serbia. In the meantime, position of Albanians was getting worse as a result of anti-propaganda led by Belgrade.

With the pretext of the call to military service and sending Albanian youth in war fronts, many young people were forced to leave and settle in different Western countries and in the USA, which greatly influenced the further reduction of the number of Albanians in Montenegro.

During the campaign of NATO air strikes against the Federal Republic of Yugoslavia, that the attack had targeted many naval and air bases where the Yugoslav army stationed on the territory of Montenegro, Montenegrin government held a constructive attitude being distanced from the federal government and giving support to Serbian opposition, even though their accommodation in Montenegro after being the target of persecution of the regime of Slobodan Milosevic, as happened with the Democrats leader Zoran Djindjic, who some years later was elected Prime Minister of Serbia but that was executed in a assassination of Serbian nationalists.

${ }^{5}$ http://www.pashtriku.org/?kat=60\&shkrimi=1027 


\section{The Political Organization of the Albanians in Montenegro}

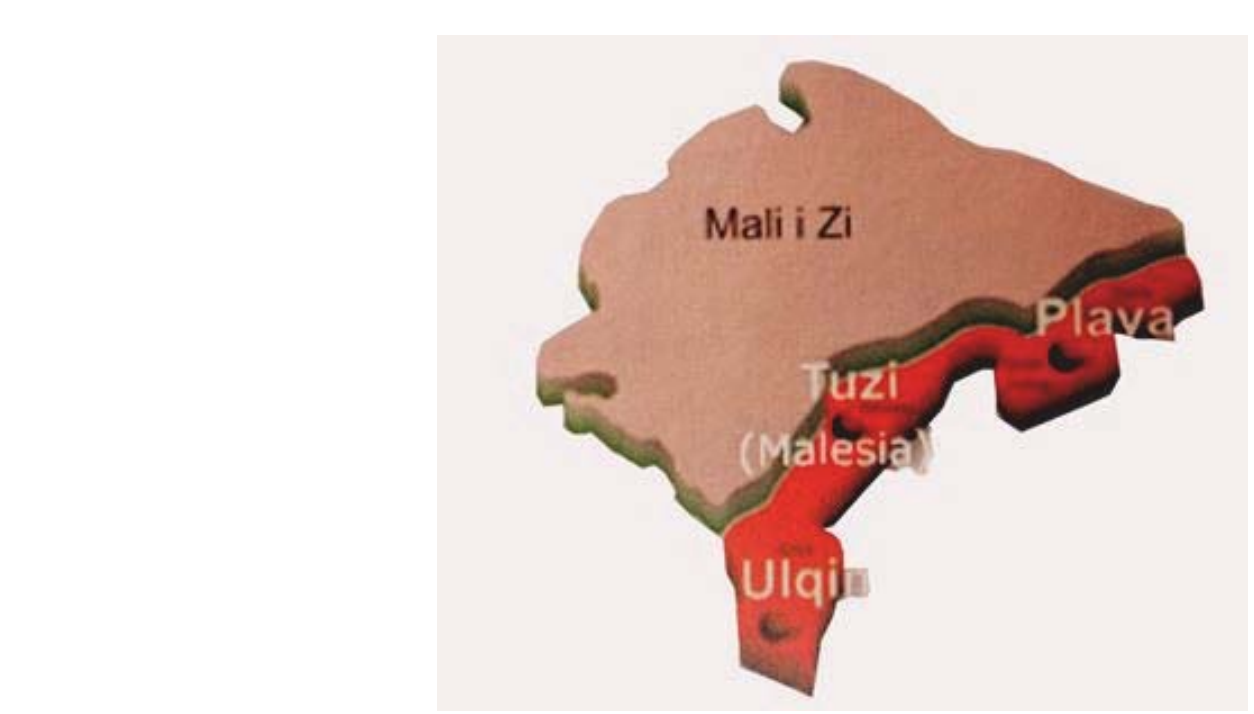

Albanian settlements in Montenegro 6

After the introduction of political pluralism in Montenegro, the Albanians were they among the first who formed their own political parties. Democratic League of Montenegro is the first Albanian formed in Montenegro. Currently there are ten Albanian political parties: This is a list of Albanian political parties based on the last election coalitions:

The Coalition "For the Union" has three political parties: New Democratic Force (FORCE), Civic Initiative Party and Movement "Perspective". Other political grouping "Albanian Coalition" with three other parties: Democratic League, the Democratic Party and the Albanian Alternative. It is the party's long-standing ethnic Albanian Democratic Union (UDSH), then Albanian Youth Alliance, and now two new parties: Civic Initiatives Albanian Party ("Party of Plav") and the Alliance Party of Albanians ("Party of Gucia), what really gets that for every 2,000 Albanian voters exists a political party.

Since the first elections held in 1990 and until last elections Albanians have always been represented in the Assembly and the number of members varies depending on their organization. The largest numbers of deputies have had in the elections of 1996 with a total of four members 7 . It is important to note that the Albanians consistently included in the Montenegrin national party lists, thus giving citizens the character of these parties even some of them have managed to be elected deputies. The case of representation usually occurs with the Prime Minister Milo Djukanovic's party - the Democratic Party of Socialists (DPS).

What characterizes the Albanians in Montenegro as the Albanians in Macedonia and the Presevo Valley is disunity and division into many smaller parties to fully suits the power. Albanians never come out with a list of national elections or local municipalities in which endanger eventual defeat. For more recent local elections for the municipality of Ulcinj Albanian parties lost their majority by the ruling DPS and if it were not great pressure of public opinion by the citizens there as well as pressure from Pristina and Tirana to create a post-election coalition was risk that the only municipality governed by Albanians be lost and fell into the hands of Montenegrin parties.

\section{The Role of Albanians in Montenegro during the Kosovo War}

KLA war for freedom and independence of Kosovo as a challenge -century helped and supported in various forms by the Albanians of Montenegro. Montenegrin Albanians were very active in accommodating Albanian citizens evicted by Serb forces especially the Dukagjin valley, then direct participation in the war of giving donations to numerous war service.

City of Rozhaja was as gateway to evicted citizens who settled in private homes of Albanians as well as religious and cultural facilities. With tens of thousands of Kosovo Albanians settled in Albanian cities in Rozhaje up in Ulcinj or through them crossed into Albania. Besides accommodation citizens became the supply of food and medicines to the KLA soldiers to the Dukagjin Operational Zone based in Rugova Mountains and in many cases the transfer of wounded soldiers and their medical treatment was done at Albanians houses in this cities.

${ }^{6}$ http://www.malesia.org/wp-content/uploads/2013/06/zonat-shqiptare-mal-i-zi2.jpg

${ }^{7}$ http://www.pobjeda.me/2012/03/06/visestranacki-zivot-u-crnoj-gori-od-stotinak-partija-prezivjela-petina/A.VApm2PmSydg 
It should definitely be noted that any institution from Kosovo did not see reasonable at least express a public thanks to the Albanians of Montenegro for their contribution during the war for the liberation of Kosovo as it did with Albania and Albanians in Macedonia. Setting a grateful slab to Rozhaje or Ulcinj would be justification for all the activity and a message for future generations witnessing that their ancestors have contributed to the freedom and independence of Kosovo.

\section{Current Problems of Albanians in Montenegro}

Even after the independence of Montenegro Albanian citizens are faced with many problems that are the basic terms of national rights. The problem that worries is that of higher education in the native language so the lack of a University that will meet their needs with new cadres. So the only option is to study in Pristina and Tirana. Even after many requests, still not opened any institution of higher education in the Albanian language. This region is known as a very strong educational and argued that the school first was opened in 1892 in Skje-Kraja ${ }^{8}$ followed in the coming years with the opening of schools in other Albanian areas. Otherwise, from these areas is also the author of the book John Buzuku first Albanian "Meshari" in 1555.

Another problem is the health because there is no single hospital as seen from the official list of hospitals published by the Ministry of Health of Montenegro ${ }^{9}$, in the region except a certain number of ambulances that in no way that do not fulfill the needs, so for any serious health problem people have to make tens of kilometers to receive necessary medical services. Not the best situation is also with information, no information in their mother tongue, where besides several local televisions there is no television or newspaper which would cover the entire territory in order to inform as quickly and efficiently to citizens.

Albanian citizens are deprived from their right to use their national symbols such as the use of the national flag and official use of Albanian language. The official documents today issued only in Serbian and Albanians do not enjoy any right in this regard. In this area occurs even greater discrimination for Albanian citizens because adjective of Albanian citizens was added Slav suffixes - iq and viq.

Currently the most preoccupying problem of this region is a migration which has taken off, especially after the visa liberalization that the EU decided to Montenegro. The causes of this migration are numerous ranging from security issue, then the lack of perspective and economic development of the region has influenced young Albanian people which have been educated in the Kosovo and Albania, based on the lack of perspective the youth remain there because the opportunity for employment is greater.

In addition to migration in western countries and the USA, Albanians from there after the liberation of Kosovo have started to settle with their families in Kosovo that is impacting greatly reduce further the number of Albanians in Montenegro.

\section{The Economic Development Perspective}

Albanian regions in Montenegro in addition of being important in geo-strategic terms are rich with underground wealth and provide favorable conditions for economic development. The main branch of the economy is tourism. In Albanian areas is developed summer tourism on the coast of Ulcinj beaches and winter tourism in the wonderful slopes near Rozhaja that appropriate investments would become attractive places for foreign tourists who practice the sport of skiing.

Another important branch is agriculture, particularly livestock because climatic conditions are such that enable the development of a highly production and processing industry of dairy products.

Characteristic of the Albanian lands in Montenegro is of Wood production and processing, especially the construction of wooden houses. It is up to government bodies to invest in forestation of high mountains which offer highquality trees with the only purpose that this area transform into an industrial wood processing which in turn will also generate new work places.

Another important sector is energy and wind energy production as a product which is supported and favored by Kiotos agreement. Knowing that Montenegro is the only ecological country in the World, this form of production is favored also by the state because it does not cause environmental pollution.

${ }^{8}$ https://vargmal.org/lg/dan2529

${ }^{9}$ http://www.mzdravlja.gov.me/ministarstvo/linkovi 


\section{Conclusions and Recommendations}

- Albanians should join the National Council and elect all its organs ranging from the Assembly of the Council. The role of the National Council as the government should be in the shade and will have the following duties:

- Design and development of policies such as economy, politics, education and health and in all areas of life where Albanians remain unrepresented

- To prepare the projects for the opening of a higher education institution and the opening of new hospitals

- Establish News Agency, Radio and the daily newspaper in order to inform the internal and external public

- To request from two Albanian states (Republic of Albania and the Republic of Kosovo) to open offices of the Council, respectively in Tirana and Pristina especially with the aim of trade and tourism promotion

- To request the Government of Albania that to Montenegro Albanians equipped with double citizenship by given to them Albanian passports.

- To prepare the project for establishment of the Association of Albanian Municipalities (including the municipality of Tuzi) that would enable the special status of political, administrative, etc. , a position which would improve the position of Albanians in particular in relation to the treatment of the Republic Montenegro for this region.

- To request the Government of Kosovo to condition the establishment of diplomatic relations with Montenegro to the advancement of human rights and the constitutional position of Albanians

- To organize the regional and international donors and potential investors conference who would allow economic development of Albanian municipalities a step that would open the way to further development in all areas taking into account the importance of economic development and its impact on sectorial policies that would increase the number of employees as well as social welfare of citizens but that will affect and the return of those who are moved.

- To establish institutional and social cooperation in all possible areas of cooperation and all levels of representation with the Republic of Kosovo, the Republic of Albania, Albanian diaspora, the Albanians of Macedonia and the Albanians of Presevo Valley

- To make the opening of higher education institutions with regional and international character which will enable not only national integration of Albanians from all Albanian territories but also the citizens of neighboring countries by promoting regional cooperation as a condition for European integration and conflict prevention.

- To develop projects for the urbanization of the Albanian lands as a precondition for the development of tourism and its promotion as an opportunity for economic development and growth of living standards.

- Request by the Government to stop the application of the introductory fee for Albanians in Kosovo and Montenegro, as did the Albanian citizens of Presevo Valley

\section{References}

Puto, Arben, Çështja shqiptare në aktet ndërkombëtare të periudhës së imperializmit (1867-1912), vëllimi I, Tiranë 1984, f. 16

http: //www. osce. org/sr/odihr/elections/montenegro/20099?download=true

http: //www. cgautentik. com/index_0_crnoj_gori. php

http: //www. pashtriku. org/?kat=60\&shkrimi=1027

http: //www. malesia. org/wp-content/uploads/2013/06/zonat-shqiptare-mal-i-zi2. jpg

http: //www. mzdravlja. gov. me/ministarstvo/linkovi

https: //vargmal. org/lg/dan2529

http: //www. pobjeda. me/2012/03/06/visestranacki-zivot-u-crnoj-gori-od-stotinak-partija-prezivjela-petina/\#. VApm2PmSydg

Zenelaj,Eqrem, Çështja shqiptare nga këndvështrimi i diplomacisë dhe gjeopolitikës së Austro-Hungarisë (1699-1918), Prishtinë 2010

Nedokucivi Balkan, Hesperia 2009, Beograd

Lisen Bashkurti, Krizat ndërkombëtare. Tiranë, 2008

Lisen Bashkurti, Mbi të drejtën ndërkombëtare dhe organizatat ndërkombëtare, Gerr, Tiranë, 2006 